\title{
A traditional technique as an alternative to plastic sheet for covering urea-treated straw : digestibility and growth trials
}

\author{
H Ben Salem 1, A Nefzaoui 1, A Messaoudi 2, T Ben Arif 2 \\ "INRAT, Laboratoire de Nutrition Animale, rue Hédi Karray, 2049 Ariana Tunisie \\ 2 Office de l'Elevage et des Pâturages, rue Alain Savary, 1002 Tunis, Tunisie.
}

In Tunisia, ammonia treatment is widely practised to improve the nutritive value of straws. however, the recent increase of anhydrous ammonia and urea costs resulted in a decrease of the number of farmers treating straws. Therefore, an attempt was made to reduce the cost of urea treatment by using mud instead of plastic sheet to cover treated straws. Preliminary results of a digestibility and growth trials are reported in this paper.

Four stacks of barley straw of $2000 \mathrm{~kg}$ each were used. The first stack was not treated and considered as control (US). The second was covered with plastic and treated with $3 \%$ anhydrous ammonia (on dry matter basis, ATS). The third was treated with urea and covered with plastic (UTSp). The fourth was treated with urea and covered with mud (UTSm). The urea treatment was performed with the equivalent of $3 \%$ ammonia ( $53 \mathrm{~g}$ urea dissolved in $250 \mathrm{ml}$ water per $\mathrm{kg}$ DM straw). A digestibility and nitrogen retention trial was carried out on 8 "Queue fine de l'Ouest» sheep arranged in a cross over design (2 animals $\times 4$ diets $\times 4$ periods). Animals were housed in metabolic cages and received straws ad libitum and $400 \mathrm{~g}$ of a commercial concentrate $(50 \%$ barley, $36 \%$ wheat bran, $6 \%$ soybean meal, 5,5\% minerals and vitamins). Chemical composition of concentrate expressed in percent DM was, 94.6, 13.8 and 9.2 for OM, CP and CF, respectively. Diets were distributed in two equal meals for a period of 15 days adaptation and 7 days of total collection. A growth trial was performed over a period of 60 days using 80 barbarine wethers ( 1 year old, live weight $30 \pm 5 \mathrm{~kg}$ ) allotted into 8 equal groups. Each diet was tested on 2 groups. Animals received straw ad libitum ( $15 \%$ refusal) and $400 \mathrm{~g}$ of commercial concentrate. Water was continuously available. Animals were weighed for two consecutive days at the start and the end of the experiment.

Ammonia and urea treatments increase nitrogen content of straws. Sheep consumed more ammonia treated straw than urea-treated straw. However the growth rates of animals were similar for ATS, UTSm and UTSp. Mud was as effective as plastic sheet in improving the nutritive value of urea-treated straw. Digestible organic matter intake (DOMi) and digestible crude protein intake (DCPi) were quite similar for UTSp and UTSm based diets and covered as well as the ATS diet maintenance requirements of animals. Daily gains of animals increased $(P<0.05)$ from 56 to 96,92 and $93 \mathrm{~g}$, for US, ATSp, UTSp and UTSm, respectively.

These results suggested that it is possible to reduce urea treatment cost using mud instead of plastic sheet. Using mud, there is no need to bale straw. Moreover, this technique is well adapted for small holders leaving in the mountains and where access to mechanisation is difficult.

DM, \%
Organic matter, g/kg DM
Crude protein content, g/kg DM
Crude fibre, g/kg DM
OM digestibility, \%
CP digestibility \%
Straw DM intake, g/day
Straw DM intake, g/day/W0.75
DOMi, g/kg LWo.75
DCPi, g/day
Liveweight gain, g/day

\section{Straws}

US
87.4
92.9
31
44.2
$58.8 b$
$32.7 b$
$720 c$
$47.8 c$
$37.7 c$
$26.5 b$
$56.6 b$

ATS

87.0

92.40

78

41.7

$63.6 a$

$51.9 a$

$910 a$

$61.1 \mathrm{a}$

$48.9 a$

$82.4 a$

$95.6 a$

\begin{tabular}{ll}
\cline { 1 - 1 } UTSm & ESM \\
84.6 & - \\
92.8 & - \\
78 & - \\
44.2 & - \\
$60.1 \mathrm{ab}$ & 0.40 \\
$54.2 \mathrm{a}$ & 0.79 \\
$829 \mathrm{~b}$ & 5.80 \\
$55.3 \mathrm{~b}$ & 0.76 \\
$42.3 \mathrm{bc}$ & 0.61 \\
$79.4 \mathrm{a}$ & 1.45 \\
$92.6 \mathrm{a}$ & 1.16
\end{tabular}

